throat, neck, and chest during the early stages of administration, which disappears entircly in a few minutes, is all that can be regarded as rirectly due to this source. Four communications ${ }^{1}$ have appeared in the London medical journals citing twelve cases in all of erythema after an enema; six of these had no anxsthetic and one was just about to have chloroform when the rash was discovered. Various explanations of the rash have been offered, but as my cases all had the particular kind of soap mentioned, and no rash resulted after the use of soft soap enemata in 400 other cases, I cannot seriously doubt that the kind of soap used is the main factor in producing the rash. On analysis the hard soap only contained a trace of iron, and was very slightly alkaline in reaction.

\section{CASE OF EMBOLISM OF THE CEN'TRAL ARTERY OF THE RETINA.}

By E. C. LoNG, L.R.C.P. LoND., M.R.C.S. ExG. PRINCIPAL MEDICAL OFFICER, BASUTOLAND.

THE patient was a well-developed Basuto aged twentytwo years, employed by the Government as a post-rider. There was no history of syphilis in his family, and he had four brothers and two sisters all living and healthy. He had never been ill as far as he could remember. On June 10th he returned from his usual post journey, and that evening complained of headache and noticed that his body was covered by an eruption. Chicken-pox was epidemic in the camp at this period. The following morning on waking he found he was quite blind in the right eye, and presented himself for treatment at the Government Hospital. The eye appeared normal, but ophthalmoscopic examination showed embolism of the right central artery. Retinoscopy showed both eyes to be hypermetropic to the extent of $2 \cdot 75 \mathrm{D}$. Three days afterwards the white haze which at the first had obscured the vessels round the centre of the disc had moved outwards, leaving the vessels in the centre well defined. The veins appeared much larger towards the periphery and the cherry spot smaller, and the white haze round it had also extended in an outward direction, while the whole fundus appeared paler. Some of the scabs of the varicellar eruption were falling off and a few fresh vesicles were seen. After this the haze gradually cleared and on July 4th the following note was made: "Edges of disc well defined. It is much whiter and along the course of the arteries is a bright white line. The fovea presents a mottled appearance of red on a white ground, the white being highly refracting and having an almost metallic appearance. The patient continues quite blind in the affected eye."

The case seems interesting from the fact of its occurring in a young subject suffering from such a simple malady as chicken-pox. Careful examination failed to detect any evidence of either cardiac or renal trouble. The only point in connexion with a possible cause of which I can think is that the evening before the embolism occurred the patient rode some thirty miles with his post, the temperature being some six degrees below freezing.

\section{REMOVAL OF A LARGE INSECT FROM THE HUMAN EAR.}

By Edward ARmitage, M.R.C.S.ENG., L.R.C.P.Loxd., D.P.H. CAMB.,

GOVERMENT PHXSTCIAN FOR THE WAILUKU DISTRICT; PHYSICIAN TO THE MALULANI HOSPITAL, ISLAND OF MAIN, HAWAIIAN ISLANDS.

CASES of insects having found their way into the human ear are frequently cited, but, so far as I am aware, few authenticated cases are to be met with in the medical journals. The following case seems to me to be worthy of notice on account of the large size of the insect in comparison with the dimensions of the passage in which it was embedded.

On the morning of July 1st, 1895, I was summoned to my office to see a Portuguese aged thirty-four, who complained that an insect was lodged in his ear and

1 The Lancet, Dec. 15th, 1888 (Dr. G. H. Burford); and Brit. Med. Jour., June 2nd, 1894 (Dr. O. W. Suckling); March 2nd, 1895 (Dr. G. E. Haur., June ; and March 30th, 1895 (Mr. Kinsey-Morgan). requested me to remove it. The patient was a man of unemotional appearance and phlegmatic temperament but he seemed to be suffering considerably. On drawing the auricle backwards and looking into the meatus, without the aid of a speculum I could not perceive anything; but after syringing with warm water for a few minutes I noticed the wing-sheaths of an insect appear. Using a pair of forceps I extracted a cockchafer. The insect was nine-twelfths of an inch long and five-twelfths of an inch broad at the junction of the head with the thorax. The long antennæ measured eight-twelfths of an inch. The creature was firmly fixed in the osseous meatus and required some force to remove it. Attached to it were particles of cerumen. The patient stated that he was awakened at 1 A.M. by a disagreeable sensation in his ear, and that in endeavouring to remove the cause he had pulled off portions of the wingsheaths. The total length of the insect from the point of the head to the termination of the wing-sheaths was probably one inch. Subsequent examination with the aural speculum showed one of the legs fixed to the tympanic membrane, but he would not undergo further treatment for its removal, expressing himself as perfectly satisfied with what had been already done. Afterwards he experienced a "rushirg noise" in the ear for about three hours, and then his aural sensations became normal.

\section{A}

OF

\section{H O S P T A L P RACTICE, BRITISH AND FOREIGN.}

Nulla autem est alia pro certo noscendi via, nisi quamplurimas et mo borum et dissectionum historias, tum aliorum tum proprias collectas habere, et inter se comparare.-MongaGNI De Sed. et Caus. Morb.. lib. iv. Proømium.

\section{ST. BARTHOLOMEW'S HOSPITAL.}

TWO CASUS OF FIBRO-ANGEIOMA OF THE NASO-PHARYNX TREATED BY OPERATION ; REMARKS.

(Under the care of Mr. ANThonY BowlBy.)

CASE 1. Fibro-angeioma of naso-pharynx; excision of upper jaw and removal of growth after ligature of the externat carotid artery.-A man aged twenty-one years attended the department for diseases of the throat at St. Bartholomew's Hospital on March 9th, 1894, on account of severe epistaxis. The history he gave was that five years previously he first had severe bleeding from the nose, and that since that time he had never been able to breathe through the nostrils; even before this time, however, he had suffered from occasional epistaxis and continued to do so subsequently. Four months before admission he consulted a medical man in Dantzig, who told him he had polypi and removed something from his left nostril, an operation which was followed by epistaxis for three weeks. Soon after this the patient came to England and was admitted as an in-patient at the Central London. Throat Hospital, where more growth was removed from the nose, with considerable loss of blood. Since this time hæmorrhage from the left nostril had been almost continuous. An examination of the patient showed that he had evidently lost much blood, for, although a thickly built, swarthy man, his lips were pale, his pupils dilated, and his pulse rapid and feeble. He was bleeding from the left nostril only, and on mopping away the blood there could be seen a growth which occupied the whole of the nasal cavity on this side. After plugging the nostril an examination of the throat showed that very little blood was running down the pharynx, but that the soft palate was bulged and moved very little on phonation or deglutition. With the finger a large growth could be felt blocking the whole of the naso-pharynx and attached to the posterior pharyngeal wall. The nose itself was not much deformed, but was distinctly broadened at its base. The patient was put to bed, kept quite quiet for several days, and fed well ; the bleeding from the nose was stopped after twelve hours by careful plugging, and the general condition improved quickly. Further examination now showed that 